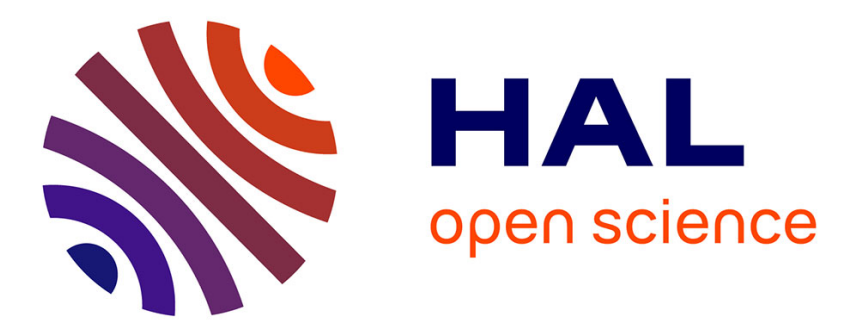

\title{
Impact of management on nutrients, carbon, and energy in aboveground biomass components of mid-rotation loblolly pine (Pinus taeda L.) plantations
}

Dehai Zhao, Michael Kane, Robert Teskey, Daniel Markewitz, Dale Greene, Bruce Borders

\section{To cite this version:}

Dehai Zhao, Michael Kane, Robert Teskey, Daniel Markewitz, Dale Greene, et al.. Impact of management on nutrients, carbon, and energy in aboveground biomass components of mid-rotation loblolly pine (Pinus taeda L.) plantations. Annals of Forest Science, 2014, 71 (8), pp.843-851. 10.1007/s13595014-0384-2 . hal-01102923

\section{HAL Id: hal-01102923 \\ https://hal.science/hal-01102923}

Submitted on 13 Jan 2015

HAL is a multi-disciplinary open access archive for the deposit and dissemination of scientific research documents, whether they are published or not. The documents may come from teaching and research institutions in France or abroad, or from public or private research centers.
L'archive ouverte pluridisciplinaire HAL, est destinée au dépôt et à la diffusion de documents scientifiques de niveau recherche, publiés ou non, émanant des établissements d'enseignement et de recherche français ou étrangers, des laboratoires publics ou privés. 


\title{
Impact of management on nutrients, carbon, and energy in aboveground biomass components of mid-rotation loblolly pine (Pinus taeda L.) plantations
}

\author{
Dehai Zhao • Michael Kane • Robert Teskey • \\ Daniel Markewitz • Dale Greene • Bruce Borders
}

Received: 22 October 2013 / Accepted: 29 April 2014 / Published online: 22 May 2014

(C) INRA and Springer-Verlag France 2014

\begin{abstract}
- Context To sustainably manage loblolly pine plantations for bioenergy and carbon sequestration, accurate information is required on the relationships between management regimes and energy, carbon, and nutrient export.

- Aims The effects of cultural intensity and planting density were investigated with respect to energy, carbon, and essential nutrients in aboveground biomass of mid-rotation loblolly pine plantations, and the effects of harvesting scenarios on export of nutrients were tested.

- Methods Destructive biomass sampling of a 12 years-old loblolly pine culture/density experiment, and analysis of variance were used to assess the effects of cultural intensity (operational vs. intensive) and six planting densities ranging from 741 to 4,448 trees ha $^{-1}$. Two harvesting scenarios (stemonly vs. whole-tree harvesting) were assessed in terms of energy, carbon, and nutrient export.
\end{abstract}

\section{Handling Editor: Gilbert Aussenac}

Contribution of the co-authors D. Zhao designed biomass sampling protocol, supervised biomass field and laboratory work, run the data analysis, and wrote the manuscript.

M. Kane supervised the culture and density study, realized the field work, and corrected the manuscript.

R. Teskey contributed to manuscript preparation.

D. Markewitz was responsible for the nutrient laboratory analysis and corrected the manuscript.

D. Greene supported the energy/nutrient laboratory analysis, provided reviews and feedback of the harvesting assessment and drafts of the manuscript.

B. Borders helped with field biomass sampling.

D. Zhao $(\bowtie) \cdot$ M. Kane $\cdot$ R. Teskey $\cdot$ D. Markewitz $\cdot$ D. Greene $\cdot$

B. Borders

Warnell School of Forestry and Natural Resources, University of

Georgia, Athens, GA 30602, USA

e-mail: zhaod@uga.edu
- Results The concentrations of energy, carbon, and nutrients varied significantly among stem wood, bark, branch, and foliage components. Cultural intensity and planting density did not significantly affect these concentrations. Differences in energy, carbon and nutrient contents among treatments were mainly mediated by changes in total biomass. Nutrient contents were affected by either cultural intensity or planting density, or both. Stem-only harvesting removed $71-79 \%$ of aboveground energy and carbon, $29-45 \%$ of N , 28-44 \% of P, $44-57 \%$ of K, $51-65 \%$ of Ca, and $50-61 \%$ of Mg.

- Conclusions Stem-only harvesting would be preferred to whole-tree harvesting, from a site nutrient conservation perspective.

Keywords Loblolly pine $\cdot$ Nutrient budget · Biomass · Energy $\cdot$ Carbon sequestration

\section{Introduction}

In the southern United States, there are 87 million hectares of forestland including 12.9 million hectares of pine plantations. These forests provide a wide range of environmental, social and economic values and, services. Loblolly pine (Pinus taeda L.) is the most commercially important southern pine species making up over $50 \%$ of the standing pine volume (1.4 billion $\mathrm{m}^{3}$ ) (Baker and Langdon 1991). In addition to producing the wood needed to supply the traditional wood products-based industries, forest landowners in this region have new promising market opportunities: providing the woody biomass feedstocks required by the bioenergy, biofuels, and biomaterials industries; and sequestering carbon for carbon credits. Intensive plantation management that includes site preparation, weed control, forest fertilization, and utilization of improved genotypes has increased potential pine plantation 
growth rates from 2 to $20 \mathrm{~m}^{3} \cdot \mathrm{ha}^{-1} \cdot \mathrm{yr}^{-1}$ in the last 50 years (Fox et al. 2007). However, it is not clear what effect management treatments such as cultural intensity and planting density have on the caloric energy value of biomass, and the total carbon and nutrient contents of plantations.

Previous studies have shown large variations in energy, carbon and nutrient concentrations among different species, and among different tree tissues for a given species (Metz and Wells 1965; Howard 1973; Zhang et al. 2009; CastañoSantamaría and Bravo 2012; Hellsten et al. 2013). We have reported how management treatments such as planting density and cultural intensity affected biomass accumulation and partitioning at the stand level (Zhao et al. 2012) and at the tree level (Subedi et al. 2012). More intensive culture with fertilization and competition control did not, but planting density did have a major influence on crown attributes of mid-rotation loblolly pine plantations such as stand-level foliar biomass and foliar nitrogen $(\mathrm{N})$ content (Akers et al. 2013). There are some published reports about foliar nutrient concentrations and their relationships with stem biomass growth in early-rotation loblolly pine plantations (Vose and Allen 1988; Zhang and Allen 1996; Barron-Gafford et al. 2003). However, there is only limited research indicating specifically how the concentrations and contents of energy, carbon (rather than biomass), and nutrients are affected by management treatments. This is unfortunate, since quantification of the energy, carbon, and nutrients in different biomass components is fundamental to designing efficient bioenergy plantation management regimes. It is an unanswered question whether the optimal planting density for energy yield is the same as the optimal planting density for stem wood production. Forest landowners may need different management regimes for short-rotation loblolly pine plantations dedicated to biofuel feedstock production compared with the management regimes used for longer-rotation plantations designed to yield sawtimber.

The amount of nutrients removed in bioenergy plantations is also an important management consideration. It is still unclear if harvesting branches along with the main stem is advantageous for energy production from loblolly pine plantations. It is known that removal of nutrients in the logging residuals at harvest can reduce soil fertility and, in turn, postharvest tree growth (Jacobson et al. 2000; Helmisaari et al. 2011) and potentially long-term forest productivity (Proe et al. 1996; Bélanger et al. 2003; Wall 2012). However, different planting densities affect biomass allocation to branches and foliage, so the costs and benefits of utilizing branches, in addition to the main stem, in stands of different stocking densities for bioenergy need to be evaluated.

The objective of this study was to quantify the concentrations and quantities of energy, carbon, nitrogen $(\mathrm{N})$, phosphorus $(\mathrm{P})$, potassium $(\mathrm{K})$, calcium $(\mathrm{Ca})$, and magnesium $(\mathrm{Mg})$ in aboveground biomass components (stem wood, bark, branches, and foliage) of mid-rotation loblolly pine plantations. Our hypotheses were as follows: (1) higher cultural intensity would increase the total content of energy, carbon, and nutrients, but decrease the concentrations of energy and carbon per unit mass because of higher growth rates; (2) there would be an optimal planting density to obtain the highest content of energy and carbon, and both higher and lower planting densities would produce lower energy yields; and (3) stem-only harvesting would be superior to total aboveground harvesting because the gain of energy from branches was insufficient to justify the increased loss of nutrients.

\section{Materials and methods}

\subsection{Study description}

This study was conducted on four installations of the loblolly pine culture and density study established by the Plantation Management Research Cooperative (PMRC) of the University of Georgia in 1997/1998 in the Upper Coastal Plain and Piedmont regions. There were two levels of cultural intensity: operational and intensive regimes (Table 1) and six levels of planting density within each level of cultural intensity $\left(741,1,483,2,224,2,965,3,706,4,448\right.$ trees $\left.\mathrm{ha}^{-1}\right)$. At each installation, there was a random assignment of culture intensities to main plots, and within a cultural intensity level the planting density was randomly assigned to subplots. This arrangement results in a split-plot design with one replication at each installation.

At each installation, PMRC cooperators selected first or second generation open-pollinated material considered good quality at time of establishment. To ensure the targeted initial density, each planting spot was double-planted and reduced to a single surviving seedling after the first growing season. Measurement plot size ranged from 0.105 ha (for 741 trees ha $\left.^{-1}\right)$ to 0.040 ha $\left(4,448\right.$ trees $\left.^{-1}{ }^{-1}\right)$.

\subsection{Field and laboratory work}

All trees in each measurement plot were measured for diameter at breast height (DBH) during the dormant season at age 12 years, and every other tree was measured for total height $(\mathrm{H})$. For the trees that were not measured for total height, estimates of total height were made using the model $\ln (H)=$ $\mathrm{b}_{0}+\mathrm{b}_{1} \mathrm{DBH}^{-1}$ separately fitted for trees with both measured total height and DBH for each plot.

In February/March of 2010, four installations were selected from this culture/density study for field biomass destructive sampling. After plot inventory, four trees per plot (one below average $\mathrm{DBH}$, one average tree, and two dominant or codominant trees) were felled and destructively sampled. A total of 
Table 1 Silvicultural treatments for the operational and intensive cultural regimes

\begin{tabular}{|c|c|}
\hline Operational regime & Intensive regime \\
\hline Tillage including subsoiling on some sites & Tillage including subsoiling on some sites \\
\hline Broadcast chemical site preparation & Broadcast chemical site preparation \\
\hline First year banded for herbaceous and woody control & Repeated herbicide application to achieve complete vegetation control \\
\hline $\begin{array}{l}\text { Fertilization: at planting, } 561 \mathrm{~kg} \mathrm{ha}^{-1} \text { of } 10-10-10 \text { fertilizer }\left(56 \mathrm{~kg} \mathrm{ha}^{-1} \mathrm{~N}\right) \\
\text { before } 8 \text { th and 12th growing seasons, } 224 \mathrm{~kg} \mathrm{ha}^{-1} \mathrm{~N}+28 \mathrm{~kg} \mathrm{ha}^{-1} \mathrm{P}\end{array}$ & $\begin{array}{l}\text { Fertilization: at planting, } 561 \mathrm{~kg} \mathrm{ha}^{-1} \text { of } 10-10-10 \text { fertilizer } \\
\left(56 \mathrm{~kg} \mathrm{ha}{ }^{-1} \mathrm{~N}\right) \text {; spring third growing season, } 673 \mathrm{~kg} \mathrm{ha}^{-1} 10-10- \\
10+\text { micronutrients }+131 \mathrm{~kg} \mathrm{ha}^{-1} \mathrm{NH}_{4} \mathrm{NO}_{3} \text {; spring fourth growing } \\
\text { season, } 131 \mathrm{~kg} \mathrm{ha}^{-1} \mathrm{NH}_{4} \mathrm{NO}_{3} \text {; spring sixth growing season, } \\
336 \mathrm{~kg} \mathrm{ha}^{-1} \mathrm{NH}_{4} \mathrm{NO}_{3} \text {; spring 8th, 10th, and 12th growing seasons, } \\
224 \mathrm{~kg} \mathrm{ha}^{-1} \mathrm{~N}+28 \mathrm{~kg} \mathrm{ha}^{-1} \mathrm{P}\end{array}$ \\
\hline
\end{tabular}

192 sampled trees ( 4 trees per plot $\times 2$ cultural intensities $\times 6$ planting densities $\times 4$ installations $)$ were harvested. The sample trees were felled at $15 \mathrm{~cm}$ above ground line, and stem measurements including $\mathrm{DBH}$, total height, height to base of live crown, diameter at the base of live crown, and taper measurements (diameter at height above butt of $0.61,1.22$, $2.44,3.66,4.88 \mathrm{~m}, \ldots$. to a point on the stem where diameter $\leq 5.1 \mathrm{~cm}$ ) were conducted.

The live crown was divided into three equal sections. Two live branches with foliage were randomly selected from each section, weighted individually, and placed in paper bags for determining dry weight in the laboratory. The green weight of all other live branches with foliage was measured by crown section, and two branches from each crown section were then randomly selected for energy/nutrient analyses. An $8 \mathrm{~cm} \mathrm{sec-}$ tion from the middle of each sampled branch was removed, resulting in 24 branch samples ( 2 branches $\times 3$ crown sections $\times 4$ trees) per plot that were placed in a paper bag. Twenty fascicles from each sample branch were randomly selected for energy/nutrient analyses. All fascicles regardless of crown position were combined to make a bulk sample for each plot. Two dead branches were sampled from each tree. Fresh weight was determined and the branches were placed in paper bags for determining dry weight in the laboratory. Fresh weight of all other dead branches was measured for each tree.

The stem of each sampled tree was marked at 1.22, 2.44, $4.88 \mathrm{~m}$ and subsequently at $2.44 \mathrm{~m}$ intervals including the last taper measurement. The stem was sectioned at the marked points and each section was weighed green in the field. A 2.5$\mathrm{cm}$ thick disk was cut from the base of each section for dry weight analysis in the laboratory and one more $2.5-\mathrm{cm}$ thick disk was cut at $2.44 \mathrm{~m}$ mark for energy/nutrient analyses. The green weight and diameter of each disk used for dry weight measurement were measured in the field. Disk samples were transported to the laboratory in sealed plastic bags. The four disks ( 1 disk $\times 4$ trees) for energy/nutrient analyses were placed in one sealed plastic bag per plot and transported to the laboratory.

In the laboratory, sub-sampled branches with foliage were oven-dried at $65^{\circ} \mathrm{C}$ to constant weight and then branches and foliage were weighed separately. Sub-sampled dead branches were oven-dried at $65^{\circ} \mathrm{C}$. Prior to drying, the bark of subsampled stem disks was separated from stem wood; and green weights of bark and stem wood were measured. The stem wood disk and bark samples were oven-dried at $105{ }^{\circ} \mathrm{C}$ to constant weight for dry weight determination.

For each sampled tree, dry weight of stem wood, bark, branches, and foliage were calculated based on the ratio of dry weight determined in the laboratory to green weight determined in the field. Stand-level total aboveground biomass and each component biomass were estimated from plot inventory data and the sampled tree biomass data with the procedure described in Zhao et al. (2012).

Energy/nutrient samples of stem, branches, and foliage were oven-dried at $60{ }^{\circ} \mathrm{C}$ to constant weight. For stem disk samples, the bark was separated from the wood, and a pieshaped section was cut from the wood disk. For branches, the wood and bark were not separated. Energy/nutrient sample material from four trees was combined by component, and then ground and mixed resulting in one composite sample of each component for each plot (i.e., 48 composite samples for each component). The energy, C, N, P, K, Ca, and Mg concentrations were analyzed for each composite sample. Gross calorific energy values of loblolly pine tissues were determined following the ASTM Standard Method Number D5468 (ASTM 2002). Pellets were prepared using $1 \mathrm{~g}$ of ground pine tissue samples using a pellet press (Parr Instrument Company, Illinois). Gross calorific energy in the pellets was determined using a Parr 1241 Adiabatic Bomb Calorimeter (Parr Instrument Company, Illinois). Carbon and nitrogen concentrations were determined after ball mill grounding with a SPEX 8000D (SPEX SamplePrep, NJ) on a CE Elantech NA 1500 (CE Elantech, NJ). P, K, Ca, and Mg were determined after block digestion with nitric acid and hydrogen peroxide following EPA Method 3050B on an OI Analytical Alpkem Flow 3000 (OI Analytical, TX) for P or a Perkin Elmer AAS (Perkin Elmer, MA) for $\mathrm{K}, \mathrm{Ca}$, and $\mathrm{Mg}$. National Institute of Standards and Technology Standard Reference Material 1575 (pine needles) and 1547 (peach leaves) were used with all analyses to maintain quality 
assurance. Stand-level energy, carbon, and nutrient contents in each biomass component were calculated as the products of energy, carbon, and nutrient concentrations and stand-level component biomass.

\subsection{Statistical analysis}

Analysis of variance with a mixed-effects model was used to examine the effects of cultural intensity and planting density on energy, carbon, and nutrient concentrations and contents in different biomass components and total aboveground biomass at the stand-level. Installation and the interaction of installation and cultural intensity were treated as random factors; cultural intensity, planting density, and their interaction were treated as fixed factors. Preplanned pairwise comparisons of least square means were conducted with Fisher's LSD (if the overall effect was significant) or with the Bonferroni method (if the overall effect was not significant) to detect differences between individual planting density level means. All statistical tests were conducted with SAS ${ }^{\circledR}$ 's PROC MIXED (Littell et al. 2006) and $\alpha=0.05$ was used for determining significance. The concentration variations among stem-wood, bark, branches, and foliage were analyzed with SAS ${ }^{\circledR}$ 's PROC GLM (SAS Institute Inc. 2010) with Tukey's multiple comparisons tests.

To assess harvesting methods from a nutrient perspective, two harvesting scenarios were simulated: (1) harvesting stem only (stem wood with bark, top diameter $7.6 \mathrm{~cm}$ ), and (2) harvesting all aboveground biomass from the forest sites (stem wood, bark, branch, and foliage). The percentage of stem wood with bark to be harvested at the stand-level was estimated using the plot inventory data and individual-tree dry weight equations developed by Pienaar et al. (1987). The removals of energy, carbon, and nutrients from the harvested stem with bark were estimated by multiplying the percentage and the contents in wood disk and bark components, then converted to the percentage of energy, carbon, and nutrients removed from stand-level contents.

\section{Results}

\subsection{Energy, carbon, and nutrient concentrations}

Neither cultural intensity nor planting density produced a significant difference in energy and carbon concentrations in any aboveground biomass component, except for a significant culture and density interaction effect on the carbon concentration in the stem bark component (Table 2). Nutrient concentrations in each biomass component were also not significantly affected by cultural intensity or planting density, with the exception of a significant planting density effect on $\mathrm{K}$ concentration in branch and $\mathrm{Ca}$ concentration in bark and foliage components.
Both average energy and carbon concentrations varied significantly among biomass components (Table 3). Caloric energy concentrations followed the decreasing order: foliage> stem bark $>$ branch $>$ stem wood. Carbon concentration followed the pattern of stem bark $>$ foliage $>$ branch $>$ stem wood. There were also significant differences in nutrient concentrations among the biomass components. The order of N, P, K, and $\mathrm{Mg}$ concentrations was as follows: foliage $>$ branch $>$ stem bark>stem wood, and $\mathrm{Ca}$ concentration was as follows: foliage $>$ stem bark $>$ branch $>$ stem wood.

\subsection{Energy, carbon, and nutrient contents}

Energy and carbon contents in all biomass components except for foliage were significantly affected by cultural intensity and planting density (Table 4). Intensive management significantly increased energy and carbon contents in stem wood, bark, branch, and thus in total aboveground biomass (Fig. 1). Energy and carbon sequestered in stem wood, bark, and total aboveground biomass generally increased with increased planting density, while energy and carbon content in branch component decreased with increased density.

More intensive management significantly increased $\mathrm{N}$ content in stem wood and bark components and in total aboveground biomass (Fig. 1). Planting density generally did not affect $\mathrm{N}$ content of any component, except that $\mathrm{N}$ content in branch and in total aboveground biomass with the lowest density (741 trees ha ${ }^{-1}$ ) was significantly higher than that with the highest density $\left(4,448\right.$ trees ha $\left.{ }^{-1}\right)$.

Cultural intensity significantly affected the $\mathrm{C}: \mathrm{N}$ ratio in bark and foliage components at 0.05 level and in stem wood at 0.07 level (Table 4 and Fig. 1), with a higher $\mathrm{C}: \mathrm{N}$ ratio in the operational culture. Planting density significantly affected the $\mathrm{C}: \mathrm{N}$ ratio in stem wood and total aboveground biomass. In general, the $\mathrm{C}: \mathrm{N}$ ratio in stem wood and total aboveground biomass increased with increasing planting density. There was no significant planting density effect on the $\mathrm{C}: \mathrm{N}$ ratio in foliage, while the differences in $\mathrm{C}: \mathrm{N}$ ratio in bark and branch components was only significant between the lowest and the highest densities ( 741 vs. 4,448 trees ha $^{-1}$ ).

There was significantly greater $\mathrm{P}$ content with intensive culture in stem wood and total aboveground biomass, while the culture intensity did not affect $\mathrm{K}$ content in any component (Table 4 and Fig. 2). P and K contents in stem wood and bark were lower, and those in branches were higher, in the lowest density stand $\left(741\right.$ trees ha $^{-1}$ ) than in some of the other higher density stands. There was no significant planting density effect on $\mathrm{P}$ and $\mathrm{K}$ contents in foliage.

More intensive management significantly increased $\mathrm{Ca}$ content in stem wood and total aboveground biomass (Table 4 and Fig. 2). The effect of planting density was significant on $\mathrm{Ca}$ content in each component and in total aboveground biomass. Mg content in stem wood, branch, 
Table 2 The $p$ value of the main effects of cultural intensity and planting density and their interactions on the concentrations of energy, $\mathrm{C}, \mathrm{N}, \mathrm{P}, \mathrm{K}, \mathrm{Ca}$, and $\mathrm{Mg}$ in biomass component of loblolly pine plantations at age 12 (using the significance level of 0.05 )

\begin{tabular}{lllllllll}
\hline & Effect & Energy & $\mathrm{C}$ & $\mathrm{N}$ & $\mathrm{P}$ & $\mathrm{K}$ & $\mathrm{Ca}$ & $\mathrm{Mg}$ \\
\hline \multirow{2}{*}{ Stem-wood } & Culture & 0.337 & 0.952 & 0.147 & 0.460 & 0.406 & 0.790 & 0.545 \\
& Density & 0.604 & 0.837 & 0.066 & 0.935 & 0.571 & 0.765 & 0.277 \\
& Culture $\times$ density & 0.657 & 0.718 & 0.694 & 0.808 & 0.992 & 0.944 & 0.279 \\
\multirow{3}{*}{ Bark } & Culture & 0.452 & 0.904 & 0.464 & 0.873 & 0.961 & 0.492 & 0.821 \\
& Density & 0.862 & 0.955 & 0.151 & 0.498 & 0.311 & 0.005 & 0.232 \\
& Culture $\times$ density & 0.253 & 0.040 & 0.752 & 0.314 & 0.306 & 0.035 & 0.206 \\
Branch & Culture & 0.177 & 0.570 & 0.576 & 0.052 & 0.204 & 0.400 & 0.877 \\
& Density & 0.158 & 0.583 & 0.460 & 0.762 & 0.034 & 0.320 & 0.179 \\
& Culture $\times$ Density & 0.903 & 0.094 & 0.944 & 0.558 & 0.227 & 0.621 & 0.579 \\
& Culture & 0.192 & 0.264 & 0.056 & 0.171 & 0.496 & 0.233 & 0.308 \\
& Density & 0.328 & 0.234 & 0.536 & 0.580 & 0.595 & 0.047 & 0.370 \\
& Culture $\times$ density & 0.830 & 0.297 & 0.332 & 0.877 & 0.406 & 0.208 & 0.234 \\
\hline
\end{tabular}

and total aboveground biomass were significantly affected by both cultural intensity and planting density, while $\mathrm{Mg}$ content in bark was significantly affected by planting density. There were no significant effects of cultural intensity or planting density on $\mathrm{Mg}$ content in foliage.

Most of the caloric energy in the stands was stored in the stem wood (Fig. 1). This accounted for 73 to $75 \%$ of the total energy content of the aboveground biomass in the four highest planting densities and 66 and $67 \%$ in the lowest planting densities. Stem wood contained only 25-35\% of aboveground $\mathrm{N}$ and $\mathrm{P}$ and $45-55 \%$ of aboveground $\mathrm{Ca}, \mathrm{Mg}$, and $\mathrm{K}$ (Figs. 1 and 2). The foliage and branch together stored 16$18 \%$ of the total energy content of the aboveground biomass, but contained 52-57\% of aboveground N, 55-58\% of aboveground $\mathrm{P}$ and $39-43 \%$ of aboveground $\mathrm{K}$ in the four highest planting densities. These two components in the lowest planting densities stored 23-26\% of the total energy content of the aboveground biomass, but contained 58-65\% of aboveground N, 64-69\% of aboveground P, and 49-52\% of aboveground $\mathrm{K}$.

\subsection{Harvesting intensity}

Stem-only harvesting removed $71-79 \%$ of aboveground carbon and energy, 29-45\% of N, 28-44\% of P, 44-57\% of K, $51-65 \%$ of $\mathrm{Ca}$, and $50-61 \%$ of $\mathrm{Mg}$ relative to that potentially removed by whole-tree harvesting in loblolly pine plantations at age 12 (Fig. 3).

\section{Discussion}

Our first hypothesis that higher cultural intensity would increase the total content of energy, carbon, and nutrients but decrease the concentrations of energy and carbon per unit mass was only partly supported by the results. Higher cultural intensity clearly increased the total content of energy, carbon, and nutrients, but it had no significant effects on their concentrations. Although energy, carbon, and nutrient concentrations differed significantly among biomass components, in a given component the concentrations were not significantly influenced by cultural intensity. The lack of differences in concentrations in response to the treatments may be due to the relatively young age of the stands, harvested at age 12 , which is close to the age of the transition from juvenile to mature wood.

We found that carbon concentration in stem wood and foliage of loblolly pine was 45.8 and $47.8 \%$, respectively, which is substantially different from the mass-based carbon concentration of $50 \%$ in dry wood and $45 \%$ in foliage that is widely accepted as a constant factor for conversion of biomass to carbon stocks (Houghton 1996; Gower et al. 2001). Carbon

Table 3 Energy, carbon, and nutrient concentrations by biomass component for loblolly pine plantations at age 12

\begin{tabular}{llllllrr}
\hline Component & Energy $\left(\mathrm{kJ} \mathrm{g}^{-1}\right)$ & $\mathrm{C}(\%)$ & $\mathrm{N}(\%)$ & $\mathrm{P}(\%)$ & $\mathrm{K}(\%)$ & $\mathrm{Ca}(\%)$ & $\mathrm{Mg}(\%)$ \\
\hline Wood & $18.9 \mathrm{~d}$ & $45.8 \mathrm{~d}$ & $0.10 \mathrm{c}$ & $0.01 \mathrm{~d}$ & $0.05 \mathrm{~d}$ & $0.06 \mathrm{~d}$ & $0.03 \mathrm{~d}$ \\
Bark & $19.7 \mathrm{~b}$ & $48.4 \mathrm{a}$ & $0.30 \mathrm{~b}$ & $0.02 \mathrm{c}$ & $0.06 \mathrm{c}$ & $0.16 \mathrm{~b}$ & $0.04 \mathrm{c}$ \\
Branch & $19.3 \mathrm{c}$ & $46.7 \mathrm{c}$ & $0.40 \mathrm{~b}$ & $0.03 \mathrm{~b}$ & $0.12 \mathrm{~b}$ & $0.14 \mathrm{c}$ & $0.06 \mathrm{~b}$ \\
Foliage & $20.6 \mathrm{a}$ & $47.8 \mathrm{~b}$ & $1.43 \mathrm{a}$ & $0.11 \mathrm{a}$ & $0.35 \mathrm{a}$ & $0.24 \mathrm{a}$ & $0.12 \mathrm{a}$ \\
\hline
\end{tabular}

Nutrient concentrations are in weight $\%$. Mean values within a column followed by the same letter are not significantly different from each other $(\alpha=0.05)$ 
Table 4 The $p$ value of the main effects of cultural intensity and planting density and their interactions on the contents of energy, C, N, P, K, Ca and Mg, and $\mathrm{C}: \mathrm{N}$ ratio among components in loblolly pine plantations at age 12 (using the significance level of 0.05 )

\begin{tabular}{|c|c|c|c|c|c|c|c|c|c|}
\hline Type & Effect & Energy & $\mathrm{C}$ & $\mathrm{N}$ & $\mathrm{C}: \mathrm{N}$ & $\mathrm{P}$ & $\mathrm{K}$ & $\mathrm{Ca}$ & $\mathrm{Mg}$ \\
\hline \multirow[t]{3}{*}{ Stem-wood } & Culture & 0.018 & 0.030 & 0.057 & 0.061 & 0.012 & 0.084 & 0.026 & 0.004 \\
\hline & Density & $<0.001$ & $<0.001$ & 0.380 & 0.044 & 0.017 & 0.007 & 0.001 & $<0.001$ \\
\hline & Culture $\times$ density & 0.320 & 0.300 & 0.647 & 0.690 & 0.989 & 0.551 & 0.872 & 0.219 \\
\hline \multirow[t]{3}{*}{ Bark } & Culture & 0.004 & 0.005 & 0.033 & 0.048 & 0.244 & 0.308 & 0.101 & 0.227 \\
\hline & Density & $<0.001$ & $<0.001$ & 0.712 & 0.051 & 0.087 & 0.031 & $<0.001$ & 0.016 \\
\hline & Culture $\times$ density & 0.034 & 0.047 & 0.471 & 0.911 & 0.389 & 0.417 & 0.030 & 0.324 \\
\hline \multirow[t]{3}{*}{ Branch } & Culture & 0.031 & 0.031 & 0.232 & 0.303 & 0.122 & 0.188 & 0.108 & 0.044 \\
\hline & Density & $<0.001$ & $<0.001$ & 0.224 & 0.379 & $<0.001$ & $<0.001$ & 0.017 & $<0.001$ \\
\hline & Culture $\times$ density & 0.801 & 0.769 & 0.935 & 0.997 & 0.979 & 0.938 & 0.818 & 0.983 \\
\hline \multirow[t]{3}{*}{ Foliage } & Culture & 0.302 & 0.370 & 0.129 & 0.041 & 0.842 & 0.652 & 0.514 & 0.114 \\
\hline & Density & 0.339 & 0.308 & 0.194 & 0.519 & 0.338 & 0.156 & 0.009 & 0.197 \\
\hline & Culture $\times$ density & 0.728 & 0.675 & 0.736 & 0.325 & 0.679 & 0.087 & 0.469 & 0.890 \\
\hline \multirow[t]{3}{*}{ Total } & Culture & 0.008 & 0.014 & 0.024 & 0.210 & 0.029 & 0.082 & 0.054 & 0.012 \\
\hline & Density & $<0.001$ & $<0.001$ & 0.079 & 0.001 & 0.308 & 0.033 & 0.002 & 0.012 \\
\hline & Culture $\times$ density & 0.205 & 0.213 & 0.569 & 0.808 & 1.000 & 0.416 & 0.885 & 0.663 \\
\hline
\end{tabular}

concentrations are known to vary with tree species and biomass component (Lamlom and Savidge 2003; Zhang et al. 2009; Castaño-Santamaría and Bravo 2012). For loblolly pine, using the $50 \%$ generic value for wood would overestimate carbon in the stem component by $4.1 \mathrm{Mg} \mathrm{ha}^{-1}$ (at age 12) and the $45 \%$ generic value for foliage would underestimate carbon in the foliage component by $263 \mathrm{~kg} \mathrm{ha}^{-1}$. This suggests that measurement of tissue-specific carbon concentrations in different tree species is necessary for quantifying stand carbon pools, accurately estimating the quantity of carbon sequestered by forests, or for developing and validating process models (Johnsen et al. 2001).

Our second hypothesis, that there would be an optimal planting density with the higher energy and carbon content, was not supported. Rather, there was a range of planting densities which supplied similar energy, carbon, and nutrient contents at the age 12 harvest. The lower planting densities had more branch energy and carbon contents than in the other densities. The three highest planting densities, however, had significantly greater stem energy and carbon contents. This indicates that for stem-only harvests for bioenergy at age 12 , planting density greater than 2,224 trees ha ${ }^{-1}$ would produce more energy, although costs or economic return are not evaluated here. If whole-trees are harvested, planting densities from 1,483 to 4,448 appear to produce very similar yields because planting density had little effect on total aboveground energy content in that planting density range. The lowest planting density, 741 trees $^{-1}$, did produce substantially less energy and carbon content in stems and whole trees, but the highest planting density, 4,448 trees $\mathrm{ha}^{-1}$, did not show a reduction in either content, compared to the middle range planting densities, even though that was a very densely packed stand. While there was no disadvantage to planting at a high density for bioenergy production, there was no particular advantage to it either, since it requires so many more seedlings to be planted on each hectare. It would likely also increase harvesting costs since stem size would be much smaller at higher densities.

With more intensive culture, the $\mathrm{C}: \mathrm{N}$ ratio in foliage and in bark decreased, but it did not decrease in the other components, including total aboveground biomass. This may suggest that the culture intensity had little influence on nutrient use efficiency. However, the $\mathrm{C}: \mathrm{N}$ ratio in stem wood, bark, and in aboveground biomass generally increased with increasing planting density. This may indicate that nutrient use efficiency is higher with greater planting densities.

Our third hypothesis, that stem-only harvesting would be superior to total aboveground harvesting because the gain of energy from branches was insufficient to justify the increased loss of nutrients, appear to be supported by our results. The foliage and branch components accounted for only $4.7-6.2 \%$ and $11.2-19.9 \%$ of total aboveground biomass, respectively, in these 12-year loblolly pine stands. However, these two components contained $52.1-65.2 \%$ of $\mathrm{N}, 54.8-68.7 \%$ of $\mathrm{P}$, and $39.1-52.4 \%$ of $\mathrm{K}$ in the aboveground biomass, depending on planting density. Whole-tree harvesting would increase the removal in harvest of $\mathrm{N}$ by $222-345 \%$, P by $272-357 \%$, K by $175-272 \%$, Ca by $154-196 \%$, and $\mathrm{Mg}$ by $164-200 \%$ compared with stem-only harvesting, while increasing the harvest of total energy by only 21-29\%. Studies of softwood plantations in Europe and the southeastern United States have 

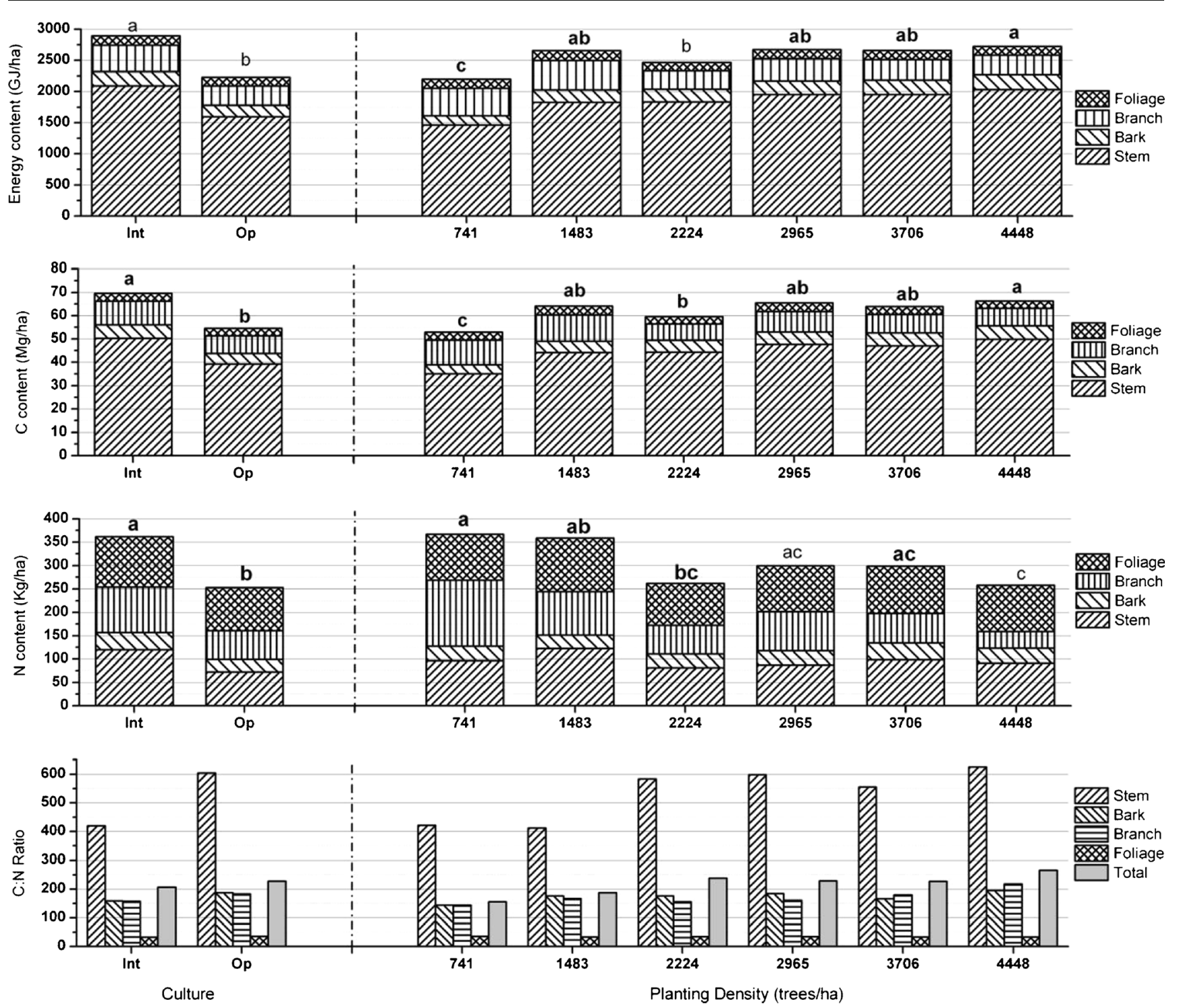

Fig. 1 Energy, carbon $(\mathrm{C})$, nitrogen $(\mathrm{N})$ contents and $\mathrm{C}: \mathrm{N}$ ratio by biomass component, culture intensity, and planting density for loblolly pine plantations in the Upper Coastal Plain and Piedmont at age 12.

found evidence of decreased second stand productivity resulting from residual removal during whole-tree harvesting when compared with stem-only harvesting, although only in the absence of silvicultural inputs such as fertilization or weed control (Scott and Dean 2006; Walmsley et al. 2009). This study indicates the removal of two to three times larger quantities of $\mathrm{N}, \mathrm{P}$, and $\mathrm{K}$ in the tree biomass by whole-tree harvesting than by stem-only harvesting, implying whole-tree harvesting has the potential to reduce site productivity. Soil fertility can be better sustained by leaving leaves and fine branches on the site during harvesting (Janowiak and Webster 2010), due to their higher nutrient concentrations. Amelioration of nutrient removals through fertilization is also possible and the common practice in managed loblolly pine plantations.
Sharing the same letter indicates that there are no significant differences in total energy, carbon, and nitrogen contents at $\alpha=0.05$ between culture levels and among planting densities, respectively

The harvesting comparisons in this study are admittedly worst-case scenarios for whole-tree harvests, since no operational harvest ever succeeds in removing all of the material on site due to market limitations and losses due to breakage during handling. However, the results do clearly show that stem-only harvests remove far fewer nutrients than whole-tree harvests and they are likely preferred on nutrient limited sites where nutrient management options are limited.

\section{Conclusions}

In this study, we found that because increased cultural intensity increased aboveground biomass, it also increased the 

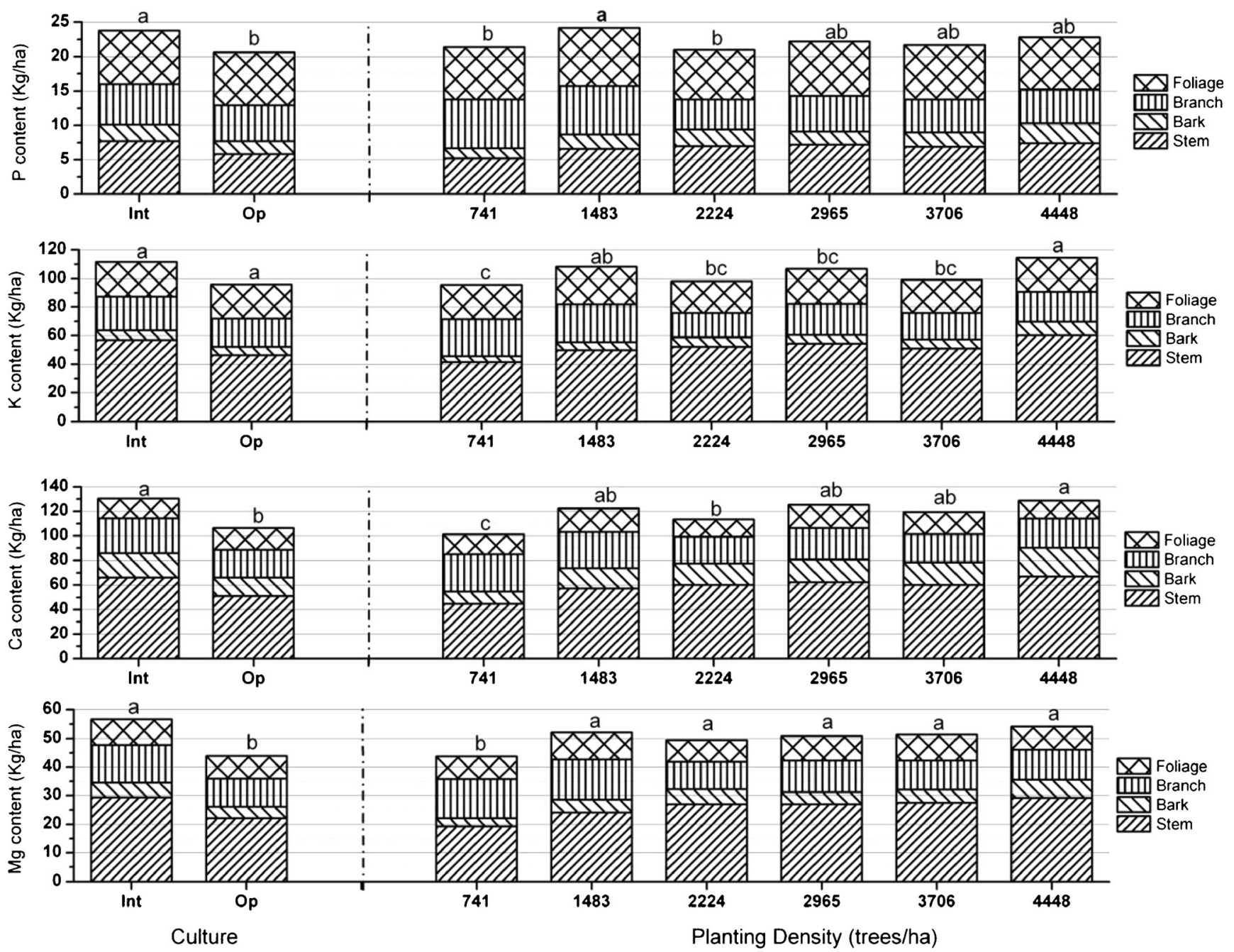

Fig. 2 Phosphorus $(\mathrm{P})$, potassium $(\mathrm{K})$, calcium $(\mathrm{Ca})$, and magnesium $(\mathrm{Mg})$ contents by biomass component, culture intensity, and planting density for loblolly pine plantations in the Upper Coastal Plain and

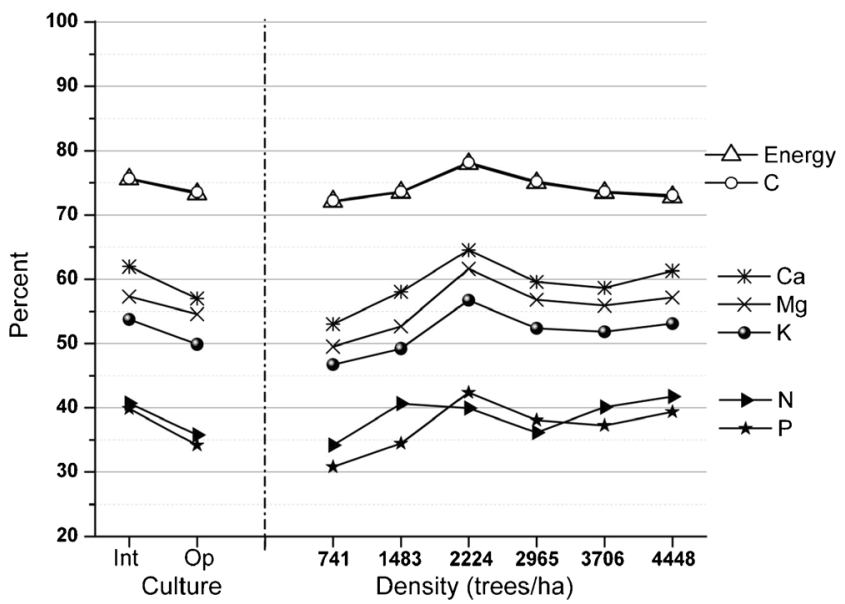

Fig. 3 Percentage of nutrients, carbon, and energy in aboveground biomass removed by stem-only harvesting from 12-year-old loblolly pine stands affected by cultural intensity and planting density
Piedmont at age 12. Sharing the same letter indicates that there are no significant differences in total $\mathrm{P}, \mathrm{K}, \mathrm{Ca}$, and $\mathrm{Mg}$ contents at $\alpha=0.05$ between culture levels and among planting densities, respectively

caloric energy content of 12 year old loblolly pine plantations. However, planting density had little effect on energy content, except at very low planting densities where it was reduced. There was no advantage to planting stands at very high densities, such as 4,448 trees ha ${ }^{-1}$ in this study, because the higher plant densities did not yield higher energy content when harvested at age 12 . We also found that a large proportion (>73\%) of the aboveground energy content in medium to high planting densities was in the stem wood. There appears to be little to no advantage to whole-tree harvesting since it removes a substantially disproportionate amount of the nutrients taken up by the trees. Overall, this study has shown that management regimes for bioenergy can be determined by optimizing biomass yield, since neither cultural regime nor planting density had a significant effect on the concentration of energy or carbon in the various aboveground biomass components, as biomass closely corresponds to energy yield in young loblolly pine stands. 
Acknowledgments This research was funded by Georgia's Traditional Industries Program (TIP) and USDA- National Institute of Food and Agriculture (Agreement No. 2011-67009-30065). We appreciated the efforts of the Plantation Management Research Cooperative (PMRC) at the University of Georgia in establishing, maintaining, and monitoring the research studies.

\section{References}

Akers MK, Kane M, Zhao D, Teskey RO, Daniels R (2013) Effects of planting density and cultural intensity on stand and crown attributes of mid-rotation loblolly pine plantations. For Ecol Manag 310:468475

ASTM (2002) ASTM D5468: standard test method for gross calorific and ash value of waste materials. ASTM International, Pennsylvania

Baker JB, Langdon OG (1991) Pinus taeda L.-Loblolly Pine. In: Burns RM, Honkala BH (Tech. Coords.) Silvics of North America, volume 1. Conifers. USDA Forest Service, Agri Handbook 654. pp

Barron-Gafford GA, Will RE, Burkes EC, Shiver B, Teskey RO (2003) Nutrient concentrations and contents, and their relation to stem growth, of intensively managed Pinus taeda and Pinus elliottii stands of different planting densities. For Sci 49:291-300

Bélanger N, Paré D, Yamasaki SH (2003) The soil acid-base status of boreal black spruce stands after whole-tree and stem-only harvesting. Can J For Res 33:1874-1879

Castaño-Santamaría J, Bravo F (2012) Variation in carbon concentration and basic density along stems of sessile oak (Quercus petraea (Matt.) Liebl.) and Pyrenean oak (Quercus pyrenaica Willd.) in the Cantabrian Range (NM Spain). Ann For Sci 69:663-672

Fox TR, Jokela EJ, Allen HL (2007) The development of pine plantation silviculture in the southern United States. J For 105:337-347

Gower ST, Krankina O, Olson RJ, Apps M, Linder S, Wang C (2001) Net primary production and carbon allocation patterns of boreal forest ecosystems. Ecol Appl 11:1395-1411

Hellsten S, Helmisaari H-S, Melin Y, Skovsgaard JP, Kaakinen S, Kukkola M, Petersson H, Akselsson C (2013) Nutrient concentrations in stumps and coarse roots of Norway spruce, Scots pine and silver birch in Sweden, Finland and Denmark. For Ecol Manag 290: $40-48$

Helmisaari H-S, Hanssen K, Jacobson S, Kukkola M, Luiro J, Saarsalmi A, Tveite B (2011) Logging residue removal after thinning in Nordic boreal forests: long-term impact on tree growth. For Ecol Manag 261:1919-1927

Houghton RA (1996) Converting terrestrial ecosystems from sources to sinks of carbon. AMBIO 25:267-272

Howard EL (1973) Heat of combustion of various southern pine materials. Wood Sci 5:194-197
Jacobson S, Kukkola M, Mälkönen E, Tveite B (2000) Impact of wholetree harvesting and compensatory fertilization on growth of coniferous thinning stands. For Ecol Manag 129:41-51

Janowiak MK, Webster CD (2010) Promoting ecological sustainability in woody biomass harvesting. J For 108:16-23

Johnsen K, Samuelson L, Teskey R, McNulty S, Fox T (2001) Process models as tools in forestry research and management. For Sci 47:2 8

Lamlom SH, Savidge RA (2003) A reassessment of carbon content in wood: variation within and between 41 North American species. Biomass Bioenergy 25:381-388

Littell RC, Milliken GA, Stroup WW, Wolfinger RD, Schabenberger O (2006) SAS ${ }^{\circledR}$ for mixed models, 2nd edn. SAS Institute, Inc, Cary

Metz LJ, Wells CG (1965) Weight and nutrient content of the aboveground parts of some loblolly pines. US Forest Service Research Paper SE-17

Pienaar LV, Burgan T, Rheney JW (1987) Stem volume, taper and weight equations for site-prepared loblolly pine plantations. PMRC Res Pap 1987-1, University of Georgia, School of Forest Resources, 11 pp

Proe MF, Cameron AD, Dutch J, Christodoulou XC (1996) The effect of whole-tree harvesting on the growth of second rotation Sitka spruce. Forestry 69:389-401

SAS Institute Inc (2010) SAS/SAT ${ }^{\circledR} 9.22$ user's guide. SAS Institute Inc, Cary

Scott DA, Dean TJ (2006) Energy trade-offs between intensive biomass utilization, site productivity loss, and ameliorative treatments in loblolly pine plantations. Biomass Bioenergy 30:1001-1010

Subedi S, Kane M, Zhao D, Borders B, Greene D (2012) Cultural intensity and planting density effects on aboveground biomass of 12-year-old loblolly pine trees in the Upper Coastal Plain and Piedmont of the southeastern United States. For Ecol Manag 267: $157-162$

Vose JM, Allen HL (1988) Leaf area, stemwood growth, and nutrition relationships in loblolly pine. For Sci 34:547-563

Wall A (2012) Risk analysis of effects of whole-tree harvesting on site productivity. For Ecol Manag 282:175-184

Walmsley JD, Jones DL, Reynolds B, Price MH, Healey JR (2009) Whole tree harvesting can reduce second rotation forest productivity. For Ecol Manag 257:1104-1111

Zhang S, Allen HL (1996) Foliar nutrient dynamics of 11-year-old loblolly pine (Pinus taeda) following nitrogen fertilization. Can J For Res 26:1426-1439

Zhang Q, Wang C, Wang X, Quan X (2009) Carbon concentration variability of 10 Chinese temperate tree species. For Ecol Manag 258:722-727

Zhao D, Kane M, Borders B, Subedi S, Akers M (2012) Effects of cultural intensity and planting density on stand-level aboveground biomass production and allocation for 12-year-old loblolly pine plantations in the Upper Coastal Plain and Piedmont of the southeastern United States. Can J For Res 42:111-122 